\title{
They Saved the Crops: Labor, Landscape, and the Struggle over Industrial Farming in Bracero-Era California
}

Cindy Hahamovitch

William \& Mary, cxhaha@uga.edu

\section{Recommended Citation}

Hahamovitch, C. (2013). Don Mitchell. They Saved the Crops: Labor, Landscape, and the Struggle over Industrial Farming in Bracero-Era California. accepted for inclusion in Arts \& Sciences Articles by an authorized administrator of W\&M ScholarWorks. For more information, please contact scholarworks@wm.edu. 
the Tokyo metropolis, she devotes a first contextualizing chapter to "World War One and the City Idea." She explains the importance of the wartime period as a genuine turning point. It was at this "moment" that economic development shifted from the nation to the cities. The sea change created new built environments using novel materials and processes (e.g., concrete, steel, electricity), a new if small middle class, and tensions between new social groups (workers versus managers, residents of the countryside versus people in first cities, and the regional chronotope versus surrounding hinterland).

Once Young establishes the profound shift around 1918, she delves into the distinctive characteristics of interwar urbanization en route to answering her central question: "How did the city become the center of modern economic and social life?" (p. 31). The question is not simply answered, in that there are urban centers and then there is Tokyo. Consequently, while Young fittingly foregrounds the dynamic transformation in her select group of chronotopes, she also discusses how these national cities were peripheral bodies in an inescapable orbit around the new national capital.

In later chapters, Young moves to "urban biography," largely setting aside the Tokyo-periphery issue to concentrate on how local people, some re-planted after a stint in the capital, re-created Okayama, Kanazawa, Niigata, and Sapporo as new cultural and social units. She brilliantly captures the Janus-faced essence of the project. Her careful depiction of various local-history movements demonstrates the methods used to remake the past to provide local identity and valorize local authority (and authorities, dead and living). While this new past was created and consumed at schools, memorialized in local histories, and made materially manifest at designated "famous sites and places" (meisho), a parallel project that associated the regional city with the future went full-steam ahead. Young associates the interwar re-creation of the regional city and modernity through the lenses of the "exhibition boom," at which local Babbittry ran rampant as regional city boosters spent lavishly to demonstrate that everything was up to date in Kanazawa City and its counterparts. The effort showcased the technology and regional economic advantages that inhered in the way modernity was being popularly understood. This was a positive association that was conjoined with anxieties about the "modern girl" and the necessary tension between what future changes might hold for the recently remade and usually hagiographic urban biography.

Young's sharpest, most convincing analysis is her tracing of the influence of the local-history movement and activities of literary leaders in Tokyo and in the regional cities. Her comprehension of the texts and teasing out of the significance of local histories and the capacity of local cultural heroes to create new social and cultural spaces reads like a satisfying mystery story. The clues are there, but the story is not without twists and turns; the end is unpredictable but convincing.

Telling the political story behind the new urban chro- notopes is more difficult. In contrast to Young's close reading of the local-history and literary movements, her perspective on second-city politics is formed from a greater distance. This may be because the evidence for explaining how individuals and group interacted to effect political change is often inconclusive. Young does show us sweeping before-and-after political changes in the four cities, but we seldom get close enough to see who is acting politically on whom. Young also seems to be somewhat of two minds about the importance of geography in influencing politics. In places she suggests that geography fixed the limits of the possible and set political parameters, but in her concluding chapter she argues for the importance of local agency. I prefer her final thoughts on this issue. Geographical determinism probably reached its end as new technologies became capable of overcoming environmental barriers. At a certain point, for example, the mountains and rivers of the "backside of Japan" (ura Nihon) probably became more of an excuse for ignoring one region than a genuine explanation of what could or could not be done.

Young's deeply layered work combining cultural and urban history is a remarkable achievement that fills in some of the blank parts of Japan's modern historical map. Beyond the Metropolis deserves a wide readership as a fundamental text on which others will surely rely in building a history of modern urbanization beyond Tokyo.

Michael Lewis University of Sydney

YukIKo Koshiro. Imperial Eclipse: Japan's Strategic Thinking about Continental Asia before August 1945. (Studies of the Weatherhead East Asian Institute, Columbia University.) Ithaca, N.Y.: Cornell University Press. 2013. Pp. xvi, 311. \$39.95.

In Imperial Eclipse, Yukiko Koshiro argues that "[u]nder the US military occupation, the Pacific War narrative eclipsed Japan's Eurasian worldview and produced Japan's postwar amnesia about its colonial empire." Aiming to "restore the comprehensive landscape of Japan's war," Koshiro "returns the Soviet Union to the scene and renames the conflict the Eurasian-Pacific War" (p. 1).

The book's central argument is that toward the end of the war, "Japanese war planners concluded that the Soviet Union had significant connections with regional nationalists that could help check US hegemonic ambitions in East Asia," and "[t]hey hoped that Soviet presence in the region would achieve a desirable balance of power vacuum created by the fall of Japan's empire" (p. 2). The first two chapters suggest the forgotten yet substantial presence of Russians in Japan, and Japan's historical affinity to it. The following two chapters demonstrate that in the early stages of the war with China, Japanese military officers and diplomats were getting accurate information on the strength of the Chinese Communist Party (CCP), its tensions with the USSR, and their respective influences in Korea. 
The next three chapters, on the process of ending the war, argue that these officers and bureaucrats knew that the USSR would eventually join the war and attack Japan.

While Koshiro has consulted extensive diplomatic and military archival and reprinted documents, a large part of her analysis is based on intelligence documents created by the Japanese army units on the continent, and to a lesser extent in Korea, as well as materials from the South Manchuria Railway Company (SMR), the Ministry of Foreign Affairs (MOFA), and the Imperial General Headquarters (IGHQ), and military orders to the garrisons in China. This part is a fascinating read, which reveals the details of war situations on the continent, and the extent and depth of Japan's intelligence operations in the area.

How were, however, these intelligence materials used for decision-making? Were key Japanese military officers, especially in the army, and other policymakers so ready to view these communist forces favorably, rather than regarding communism as one of the biggest threats to Japan's national security, along with the Allied attacks? In the desperate last moment of the survival of their nation, were they in a position to decide not to put up a strong resistance against the USSR's advance on the Manchurian and North Korean fronts, based on a calculated grand vision for the postwar order in Northeast Asia? Indeed, there were some, especially Takagi Sōkichi, who expressed such a postwar vision in March 1945 (pp. 182, 202). It is unclear, however, whether this view was dominant in the decision-making process at the Supreme Council for the Direction of War (Saikō sensō shidō kaigi) in August. The book suggests that one particular action taken by Foreign Minister Tōgō Shigenori-his deliberate delaying of a meeting with the Soviet ambassador, Yakov Malik (p. 240) - may have been key to answering some of these questions, but the author does not elaborate on this. Her main theme, therefore, will pose a further debating point in the view of recent works on the Cold War in Asia, as well as new scholarship according the USSR a more significant role in the Pacific War than was previously thought.

Koshiro also makes a few important points on the scholarship of modern Japanese history. She argues that until recently the "Pacific War" was examined predominantly from the perspective of the relationship between the U.S. and Japan, and she rightly points out that this resulted in Japan's amnesia about its colonial past, or more precisely Japan's unfulfilled moral responsibility not only to the Allied countries, but also to those in Japan's and Allies' colonies in Asia and the Pacific region. It is for precisely this reason that Kurasawa Aiko, among others, has argued that what is commonly called the Pacific War is a part of a broader war, the Asia-Pacific War (Ajia Taiheiyō Sensō). It would have been good to know how Koshino understood Kurasawa and others' argument.

The book reinforces another critical point, made by John Dower and Sheldon Garon: that there has been a gap between English-language-based scholarship on modern Japanese history, which was previously dominated by the modernization theory, and Japanese-language-based scholarship, which was written mostly in the Marxist framework. This once-significant gap is narrowing as more diverse angles are evident on both sides, and more scholars are integrating scholarship in both languages. Works like this book will enhance this trend, making the scholarship even richer and fuller.

Three last important points should be made. First, Koshiro's statement about the "ultimate power" to be given to the Supreme Council for the Direction of War (p. 3) needs to be qualified, as Itō Takashi elaborates in "Kaisetsu" (in Itō Takashi and Takeda Tomoki, eds., Shigemitsu Mamoru: Saikō sensō shidō kaigi kiroku, shuki [2004], pp. 371, 373, 374, 377, 378). Second, certain confusion in her understanding of the organizational structure can be detected in her use of the names of the offices in charge of civilian intelligence activities. Koshino uses the term "the Cabinet Information $\mathrm{Bu}$ reau” for Naikaku jōhōbu (pp. 43, 44, 99, 109, 112, 113). It is normally translated as "the Cabinet Information Department," which was created in September 1937 to succeed the Cabinet Information Committee. She describes Jōho kyoku as "the Intelligence Bureau ... of the Japanese Ministry of Foreign Affairs" (p. 48). It is normally translated as "the Board of Information," and it was not a part of the MOFA. The Board of Information was created in December 1940 as a part of Konoe's administrative reform. It was intended to expand the capacity of the Cabinet Information Department. While it absorbed the Department of Information of the MOFA, and became the clearinghouse for civilian intelligence, its duties went beyond the area of civilian intelligence, and encompassed the areas of diverse information-related activities, such as propaganda and the national spiritual mobilization movement. Third, a bibliography at the end, with all the key primary sources and select secondary sources, would have been useful for readers.

\section{Томоко Акамі Australian National University}

Aaron Stephen Moore. Constructing East Asia: Technology, Ideology, and Empire in Japan's Wartime Era, 1931-1945. Stanford, Calif.: Stanford University Press. 2013. Pp. xii, 314. Cloth $\$ 55.00$, e-book $\$ 55.00$.

Historians interested in how science and technology shaped Japan and its wartime empire have been rewarded with a handful of excellent studies published over the past five years by Yang Daqing, Janis Mimura, and Mizuno Hiromi. Aaron Stephen Moore's book adds to this illustrious canon. Moore argues that technology was "much more than simply advanced machinery and infrastructure" (p. 6). Rather, "it included a subjective, ethical, and visionary dimension" (p. 6) and "constituted a widespread force of rationalization" (p. 5). Moore documents how technology-described by his oft-employed phrase "technological imaginary"- 